\title{
Response of soil organic matter dynamics to conversion from tropical forest to grassland as determined by long-term incubation
}

\author{
Luitgard Schwendenmann • Elise Pendall
}

Received: 15 December 2007 /Revised: 8 April 2008/Accepted: 14 April 2008 /Published online: 28 May 2008

(C) The Author(s) 2008

\begin{abstract}
Understanding soil organic carbon (SOC) responses to land-use changes requires knowledge of the sizes and mean residence times (MRT) of specific identifiable SOC pools over a range of decomposability. We examined pool sizes and kinetics of active and slow pool carbon (C) for tropical forest and grassland ecosystems on Barro Colorado Island, Panama, using long-term incubations (180 days) of soil and stable $\mathrm{C}$ isotopes. Chemical fractionation (acid hydrolysis) was applied to assess the magnitude of nonhydrolysable pool C (NHC). Incubation revealed that both grassland and forest soil contained a small proportion of active pool $\mathrm{C}(<1 \%)$, with MRT of $\sim 6$ days. Forest and grassland soil apparently did not differ considerably with respect to their labile pool substrate quality. The MRT of slow pool $\mathrm{C}$ in the upper soil layer $(0-10 \mathrm{~cm})$ did not differ between forest and grassland, and was approximately 15 years. In contrast, changes in vegetation cover resulted in significantly shorter MRT of slow pool $\mathrm{C}$ under grassland (29 years) as compared to forest (53 years) in the subsoil (30$40 \mathrm{~cm}$ ). The faster slow pool turnover rate is probably associated with a loss of $30 \%$ total $\mathrm{C}$ in grassland subsoil compared to the forest. The NHC expressed as a percentage of total $\mathrm{C}$ varied between $54 \%$ and $64 \%$ in the surface soil and decreased with depth to $\sim 30 \%$. Grassland NHC had
\end{abstract}

L. Schwendenmann $(\bowtie)$

Tropical Silviculture and Forest Ecology, Burckhardt Institute,

University of Goettingen,

Buesgenweg 1,

37077 Goettingen, Germany

e-mail: 1schwen@gwdg.de

E. Pendall

Department of Botany and Program in Ecology,

University of Wyoming,

1000 E. University Ave.,

Laramie, WY 82071, USA considerably longer MRTs (120 to 320 years) as compared to slow pool C. However, the functional significance of the NHC pool is not clear, indicating that this approach must be applied cautiously.

Keywords Active pool carbon - Forest conversion .

Grassland · Incubation - Mean residence time .

Non-hydrolysable carbon · Slow pool carbon .

Stable C isotopes · Panama

\section{Introduction}

Soil organic carbon (SOC) is a complex mixture of carbon (C) compounds derived from plants, animals, and microbes, which vary greatly in their amount and decomposition dynamics. However, predictive understanding of SOC responses to climate, and land-use changes requires knowledge of the sizes and mean residence times (MRT) of specific identifiable SOC pools. In models, SOC is often grouped into three conceptual pools to characterize long- and short-term changes in soil C storage and decomposition rates (Parton et al. 1987). The 'active,' 'labile,' or 'fast' pool is assumed to be composed of microbial biomass and easily decomposable compounds (e.g., proteins and polysaccharides) from leaf litter and root-derived material with short MRT (from days to years). The 'slow' or 'intermediate' pool is understood to consist of refractory components of litter, weakly sorbed carbon, and MRT from 10 to more than 100 years. The 'passive', 'resistant', 'recalcitrant', or 'stable' pool is considered to be composed of aliphatic compounds, often mineralstabilized, with MRT on the order of $10^{3}$ years (Trumbore 1997; Paul et al. 2001; von Lützow et al. 2006).

Different fractionation techniques (biological, chemical, and physical) are employed to isolate SOC pools and to 
assess $\mathrm{C}$ dynamics. Long-term laboratory incubation (biological fractionation scheme) is used to approximate the natural process of microbial degradation in the soil to estimate active and slow pool C sizes and their MRTs (Townsend et al. 1997; Paul et al. 2001). This method assumes that microbes will mineralize the most labile $\mathrm{C}$ first (Fig. 1, schematic drawing). The slow pool will be mineralized more slowly over a longer period (Townsend et al. 1997; Paul et al. 2001). Active and slow pools are considered to be sensitive to land management (McLauchlan and Hobbie 2004) and depth (Fierer et al. 2003).

Several chemical fractionation methods are used to isolate fractions that represent the passive $\mathrm{C}$ pool in soils, the most common of which is acid hydrolysis by 6- $\mathrm{M} \mathrm{HCl}$ (Leavitt et al. 1996; Six et al. 2002; Plante et al. 2006a). The acid solution hydrolyses compounds that are potentially biodegradable, e.g., proteins, nucleic acids, or polysaccharides (=hydrolysable fraction), while more recalcitrant macromolecules (e.g., highly aliphatic compounds) remain in the residue (=nonhydrolysable $\mathrm{C}, \mathrm{NHC}$ ). However, the resistance of compounds to laboratory hydrolysis may not be paralleled by a strong resistance to natural biological degradation in the soil (Poirier et al. 2006; Helfrich et al. 2007), suggesting that hydrolysis may not accurately quantify resistant soil C (Balesdent 1996; Trumbore and Zheng 1996).

Combining fractionation techniques with ${ }^{13} \mathrm{C}$ natural abundance offers a tool to test the contribution of different soil organic matter fractions to mineralization (Paul et al. 2001). The ${ }^{13} \mathrm{C}$ natural abundance technique can be applied in plant/soil systems where the photosynthetic pathway of the vegetation has changed (Balesdent and Mariotti 1996), for example, where $\mathrm{C}_{4}$ grass (average $\delta^{13} \mathrm{C}$ value of $-11 \%$ ) grows on soils derived from $\mathrm{C}_{3}$ vegetation (average $\delta^{13} \mathrm{C}$ value of -27\%o; Smith and Epstein 1971).

In Central Panama as well as other parts of the humid tropics, the native tropical forest is undergoing a rapid conversion into agricultural land, mainly pastures (Condit et al. 2001). The present study provides a unique opportunity to assess how changes in vegetation can affect soil $\mathrm{C}$ stocks and dynamics, independent of land management such as cropping or grazing. Previous measurements on water stable aggregates and density fractions at the same study sites revealed that simply altering the vegetation cover did not alter the soil aggregate structure but led to a loss of about $25 \%$ of total SOC (0-50 cm depth; Schwendenmann and Pendall 2006). In the present study, we conducted long-term incubations to quantify changes in pool sizes and MRT of active and slow C pools in forest and grassland soils taken from different depths. Furthermore, we estimated the non-hydrolysable $\mathrm{C}$ pool to assess if this approach provides meaningful resistant pool $\mathrm{C}$ and allows insight into carbon stabilization at the sites in question. We also measured stable $\mathrm{C}$ isotopes in the different pools to quantify changes of $\mathrm{C}$ resulting from vegetation change. We expected that active pool $\mathrm{C}$ and its MRT would differ between forest and grassland soils but that slow pool C would be less affected and that these changes would be soildepth-dependent. Results from this study should improve models predicting effects of tropical forest conversion to grasslands on $\mathrm{C}$ cycling at local to global scales.

\section{Material and methods}

Site description

The study was conducted on Barro Colorado Island (BCI; $9^{\circ} 10^{\prime} \mathrm{N}, 79^{\circ} 51^{\prime} \mathrm{W}$ ), which is located in the middle of the Panama Canal. The mean annual temperature of the region is $26^{\circ} \mathrm{C}$ (STRI 2006). Average total yearly rainfall is $2,600 \mathrm{~mm}$ per year, with a distinct dry season (approximately from mid-December to the end of April). The vegetation on BCI is classified as Tropical Moist Forest in the Holdridge life zone system (Leigh et al. 1996). Our study sites were located on the north side of the island close to the Miller lighthouse (UTM-626284 E, $1013458 \mathrm{~N}$ ). The soils are oxisols, developed in andesite parent material (Yavitt 2000), with clay mineralogy dominated by kaolinite (Schwendenmann and Pendall 2006). We selected two different land-use types, undisturbed forest and grassland. The forest site appeared undisturbed by pre-twentieth century clearing (Condit et al. 1996). At the adjacent grassland site, the forest was cut around 90 years ago to set up a lighthouse for the Panama Canal and has been maintained by burning and cutting. At the time of sampling, the vegetation of the grassland site was dominated by wild sugarcane (Saccharum spontaneum), a $\mathrm{C}_{4}$ plant. Soil texture in both land-use types was sandy clay loam throughout the profile. Small macroaggregates $(250$ $2,000 \mu \mathrm{m})$ accounted for $60 \%$ to $80 \%$ of the total sample mass under forest and grassland (Schwendenmann and Pendall 2006). In the upper layers (0- to 5- and 5- to $10-\mathrm{cm}$ depth), $\mathrm{pH}$ ranged from 4.9 (forest) to 6.6 (grassland), and in the subsoil (30- to $40-\mathrm{cm}$ depth), $\mathrm{pH}$ was 4.9 for forest and 4.6 for grassland. The higher $\mathrm{pH}$ in surface grassland soil is most likely due to regular burning. The soil profile (to $50-\mathrm{cm}$ depth) contained between $64 \pm 8$ (grassland) to $84 \pm 9$ (forest) $\mathrm{Mg} \mathrm{C}$ ha $^{-1}(P>0.05$; Schwendenmann and Pendall 2006).

Field sampling and soil analyses

We selected three paired plots at upper, middle, and toe-slope positions in forest and grassland. The plots were separated by about $200 \mathrm{~m}$ along the slope and by $\sim 100 \mathrm{~m}$ between forest and grassland. Samples were taken from one soil pit per plot from the dark reddish brown A horizon (0- to 5- and 5- to $10-\mathrm{cm}$ depth) and the reddish, stoney B horizon (30- to $40-\mathrm{cm}$ depth) in January 2004 (beginning of dry season). For the 
incubation experiment, field-moist subsamples were kept at $4^{\circ} \mathrm{C}$ until analysis. To estimate the soil field moisture content, subsamples were dried at $105^{\circ} \mathrm{C}$ for $48 \mathrm{~h}$.

\section{Incubation experiment}

Incubations were performed using 15 (0- to 5 -cm depth) or $20 \mathrm{~g}$ (5- to 10- and 30- to 40-cm depth) field-moist soil. Before incubation, the soil was sieved $(8 \mathrm{~mm})$, and roots were removed. Duplicate sub-samples from each of the three replicate profiles were placed in $50-\mathrm{ml}$ polystyrene beakers, which had small holes punched into the bottom, and pre-combusted glass-fiber filter paper lining the beaker for drainage. The soil was gently compressed to simulate field bulk density, which ranged between $0.85 \mathrm{Mg} \mathrm{m}^{-3}$ and $0.99 \mathrm{Mg} \mathrm{m}^{-3}$, and did not differ significantly among depths or between land-use types (Schwendenmann and Pendall 2006). Soil-filled and blank jars were flushed with dry, compressed air $\left(\mathrm{CO}_{2}\right.$ concentration, $377 \mathrm{ppm} ; \delta^{13} \mathrm{CO}_{2}=-44 \%$ ) and then incubated in dark growth chambers at $25^{\circ} \mathrm{C}$. The $\mathrm{CO}_{2}$ production was periodically (at intervals ranging from 1 to 20 days) determined using an infrared gas analyzer (LI820, LI-COR, Lincoln, Nebraska, USA) on 15-ml headspace samples. A calibration curve (power function) was established with standards of $372,1,000$, and $2,700 \mathrm{ppm} \mathrm{CO}_{2}$. Samples ranged between 500 and $5,000 \mathrm{ppm} \mathrm{CO}_{2}$. After each sampling, the jars were flushed with compressed air. When necessary, deionized (DI) water was added to maintain the original field moisture content, which ranged between $30 \%$ and $50 \%$. For similar soil types, soil respiration rates were highest at soil moisture contents between $30 \%$ and $50 \%$, indicating the optimal range for microbial activity (Schwendenmann et al. 2003).

Carbon mineralization rates were expressed on a per unit oven-dry soil basis (microgram $\mathrm{C}$ per gram soil per day) and on a per unit total $\mathrm{C}\left(C_{\mathrm{t}}\right)$ basis (milligram $\mathrm{C}$ per gram $C_{\mathrm{t}}$ per day). The cumulative $\mathrm{CO}_{2}$ mineralized $\left(C_{\text {cum }}\right)$ was estimated by linear interpolation between sampling dates and adding up the daily mineralization rates.

\section{Acid hydrolysis}

The resistant carbon fraction was determined by acid hydrolysis (Paul et al. 2001), using a flat bottom flask with

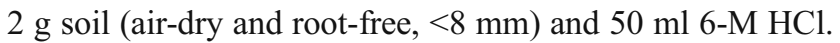
The soil/acid mixture was boiled at $100^{\circ} \mathrm{C}$ for $18 \mathrm{~h}$ using a heating plate. After boiling, the suspension was filtered, and the remaining solid fraction on the filter paper was rinsed with DI water. The residue was dried, weighed, and ground for $\mathrm{C}$ and ${ }^{13} \mathrm{C}$ analyses.

Previous studies indicate that major plant components like lignin and cellulose (Kögel-Knabner et al. 1994) are resistant to acid hydrolysis. Thus, in a subset of samples, the light fraction, which is considered to be mainly composed of fresh organic residues, was removed by density fractionation using sodium polytungstate (SPT) with a density of $1.85 \mathrm{~g} \mathrm{~cm}^{-3}$. After density fractionation (pretreatment), samples were washed with distilled water and then subjected to acid hydrolysis as described above.

\section{Isotopic composition of carbon pools}

The $\mathrm{C}$ content and ${ }^{13} \mathrm{C}$ were measured for pre- and postincubated soil samples and non-hydrolysable material using high-temperature combustion (NCS 2500, CE Elantech, Lakewood, NJ, USA) and an isotope-ratio mass spectrometer (Isoprime, Micromass, Manchester, UK). Stable C carbon isotope ratios are expressed as:

$\delta^{13} \mathrm{C}(\% 0)=\left(\frac{\mathrm{R}_{\text {sample }}}{\mathrm{R}_{\text {standard }}}-1\right) \times 1000$

where $R={ }^{13} \mathrm{C} /{ }^{12} \mathrm{C}$ and the standard was V-PDB. The precision of the $\delta^{13} \mathrm{C}$ analysis was $\pm 0.2 \%$.

Variations in $\delta^{13} \mathrm{C}$ of the $\mathrm{CO}_{2}$ that evolved from the surface soil layer $(0-5 \mathrm{~cm})$ during the incubations were determined using gas chromatography-isotope ratio mass spectrometry (GC-IRMS, Micromass, Manchester, UK). Respired ${ }^{13} \mathrm{CO}_{2}$ signature was measured periodically between 1 and 110 days after the start of the incubation as described by Pendall and King (2007).

Active and slow pool sizes and mean residence times

Daily mineralization rates were used to calculate active and slow pool sizes and turnover rates based on the two-pool constrained model described by Paul et al. (2001; Eq. 2).

$\frac{\mathrm{dC}}{\mathrm{dt}}=C_{\mathrm{a}} e^{-\left(k_{\mathrm{a}} \times \text { days }\right)}+C_{\mathrm{s}} e^{-\left(k_{\mathrm{s}} \times \text { days }\right)}$

where $\mathrm{dC} / \mathrm{dt}$ was the daily $\mathrm{C}$ mineralization rate, $C_{\mathrm{a}}$ is the size of the active pool, $k_{\mathrm{a}}$ is the turnover rate for the $C_{\mathrm{a}}$ pool, $C_{\mathrm{s}}$ is the size of the slow pool, $k_{\mathrm{s}}$ is the turnover rate for the slow pool. The slow pool comprised the total $\mathrm{C}$ pool minus the sum of active pool $\mathrm{C}$ and $\mathrm{NHC}$ (pretreated samples). Active pool size and turnover rates $(k)$ per day of active and slow pool $\mathrm{C}$ were estimated by applying the exponential decay model (Eq. 2), using a nonlinear regression (PROC NLIN, Method = Marquardt, SAS, version 8.2, SAS Institute Inc. Cary, NC, USA) that adjusted for the curvilinear relationship of the $\mathrm{C}$ mineralization between sampling points (Paul et al. 2001). $C_{\mathrm{a}}$ and $C_{\mathrm{s}}$ were expressed on a per unit total $\mathrm{C}$ basis $\left(\mu \mathrm{g} \mathrm{C} \mathrm{g}^{-1} C_{\mathrm{t}}\right)$. We report the turnover rate as MRT (in days or years), which is an inverse function of the turnover rate $\left(k^{-1}\right)$. 
Proportion of grassland-derived $\mathrm{C}$ of respired $\mathrm{CO}_{2}$ and non-hydrolysable carbon

The $\delta^{13} \mathrm{C}$ values of respired $\mathrm{CO}_{2}$ from active pool $\mathrm{C}$ were used to estimate the proportion of "new" C [grasslandderived $\mathrm{C}\left(C_{4}\right)$, incorporated to the soil since vegetation change] utilized by microbes. We applied a simple massbalance approach (Balesdent and Mariotti 1996), assuming that the 'new' $\mathrm{C}\left(C_{\text {new }}\right)$ was isotopically similar to fresh grass residue and that 'old' $\mathrm{C}$ was similar to $\delta^{13} \mathrm{C}$ of carbon in pre-incubated forest soil.

$$
\begin{aligned}
\% \mathrm{C}_{\text {new }}= & \frac{\left(\text { active pool } \delta^{13} \mathrm{CO}_{2 \text { grassland }}-\delta^{13} \mathrm{C}_{\text {pre-incubated forest soil }}\right)}{\left(\delta^{13} \mathrm{C}_{\text {grass residue }}-\delta^{13} \mathrm{C}_{\text {pre-incubated forest soil }}\right)} \\
& \times 100
\end{aligned}
$$

We considered the $\delta^{13} \mathrm{C}$ of $C_{\mathrm{a}}$ under grassland to be characterized by $\mathrm{CO}_{2}$ that evolved over the first 6 days of the incubation period (based on the MRT of $\mathrm{C}_{\mathrm{a}}$ ), although we corrected this for the contribution of slow pool $\mathrm{CO}_{2}$ as described by Pendall and King (2007).

The proportion of $C_{4}\left(\% \mathrm{NHC}_{\text {new }}\right)$ for grassland $\mathrm{NHC}$ was calculated using Eq. 3, where forest $\mathrm{NHC}$ was used as 'old' $\mathrm{C}$ and $C_{4}$ residue $(-16.2 \% \pm \pm 4.2 \%$ ) as 'new' C. The MRT (in years) for NHC was estimated using a first-order decay model (Six and Jastrow 2002).

$\operatorname{MRT}_{\mathrm{NHC}}($ years $)=\frac{-t}{\ln \left(\frac{C_{\mathrm{t}}}{C_{0}}\right)}$

where $t$ is the time since conversion (here 90 years), $C_{\mathrm{t}}$ is the content (in $\mathrm{g} \mathrm{C} \mathrm{kg}^{-1}$ ) of the remaining forest-derived $\mathrm{NHC}$ in the grassland soil at the time of sampling, and $C_{0}$ is the NHC content present under the forest at the time of sampling.

\section{Statistical analyses}

Differences in $\mathrm{C}$ mineralization, pool sizes, MRT, and $\delta^{13} \mathrm{C}$ among depths and between vegetation types were tested employing a two-way analysis of variance and Tukey's honestly significant differences post hoc test $(n=3, P<$ 0.05 ). We used Pearson product-moment correlation to identify relationships among parameters. Statistical analyses were conducted with Statistica 7.1 (StatSoft, Tulsa, OK, USA).

\section{Results}

Carbon mineralization

The emission of carbon dioxide (per gram soil C) from incubated forest and grassland soils followed the same general pattern (Fig. 1), with highest rates from surface soils and lowest rates from subsoils. Respiration rates were about 0.6 to $1.4 \mathrm{mg} \mathrm{C}$ per gram $\mathrm{C}$ per day during the initial active pool phase, which lasted approximately 10 days. The rates dropped considerably after 4 weeks and remained relatively constant at less than $0.2 \mathrm{mg} \mathrm{C}$ per gram $\mathrm{C}$ per day during the slow pool phase (Fig. 1). Highest rates were observed in surface soils, indicating higher microbial activity and lowest rates in forest subsoils.

Cumulative $\mathrm{C}$ mineralization in 0 - to 5 -cm depth was $1,151 \mu \mathrm{g} \mathrm{C}$ per g soil per 180 days in the forest and $1,130 \mu \mathrm{g}$ $\mathrm{C}$ per gram soil per 180 days in the grassland soil $(P>0.05$; Table 1) or $28 \mathrm{mg} \mathrm{C}$ per gram C per 180 days for both forest and grassland soil. This represented a loss between $2.6 \%$ (forest) and $2.9 \%$ (grassland) of total soil $\mathrm{C}$ during the 6 months of incubation. The percentage of total C mineralized in subsoil samples was significantly higher in grassland than forest $(1.5 \%$ vs. $0.9 \%$, respectively; Table 1$)$. Total cumulative $\mathrm{C}$ mineralization was closely correlated with total soil C content (grassland, $r^{2}=0.90$; forest, $r^{2}=0.99$ ).

Active and slow pool sizes and mean residence times

Based on the curve analysis (Eq. 2), active pool C was $<1 \%$ of soil $\mathrm{C}$ and did not differ between grassland and forest soils (Table 2). The highest proportion of active pool C $(0.7 \%$ under forest and $0.9 \%$ under grassland) was found in 0 - to $5-\mathrm{cm}$ depth; significantly less was found in the subsoil, with $0.4 \%$ in grassland and $0.3 \%$ in forest.

The MRT of active pool $\mathrm{C}$ in the surface soil $(0-5 \mathrm{~cm})$ was approximately 6 days for both forest and grassland, and decreased significantly with depth (Table 2). The MRT of slow pool $\mathrm{C}$ was 12 years in surface soil in the grassland and 15 years in the forest $(P>0.05)$. Under both vegetation types, slow pool MRT increased with depth. A considerably longer MRT was estimated for the forest subsoil (53 years) as compared to the grassland soil (29 years; $P<0.05$ ).

Non-hydrolysable carbon

The NHC (no pretreatment) represented $54-64 \%$ of the total $\mathrm{C}$ in the surface soil under both land-use types (Table 3). The proportion of non-hydrolysable $\mathrm{C}$ decreased significantly with depth. In the subsoil, NHC made up a 
Fig. $1 \mathrm{C}$ mineralization rates over the course 180 days for forest and grassland soil $(0-$ to 5-, 5- to 10-, and 30- to 40-cm), Barro Colorado Island, Panama. Error bars are \pm 1 standard deviation, $n=3$. The daily mineralization rates were used as inputs for the two-pool model (Eq. 2)

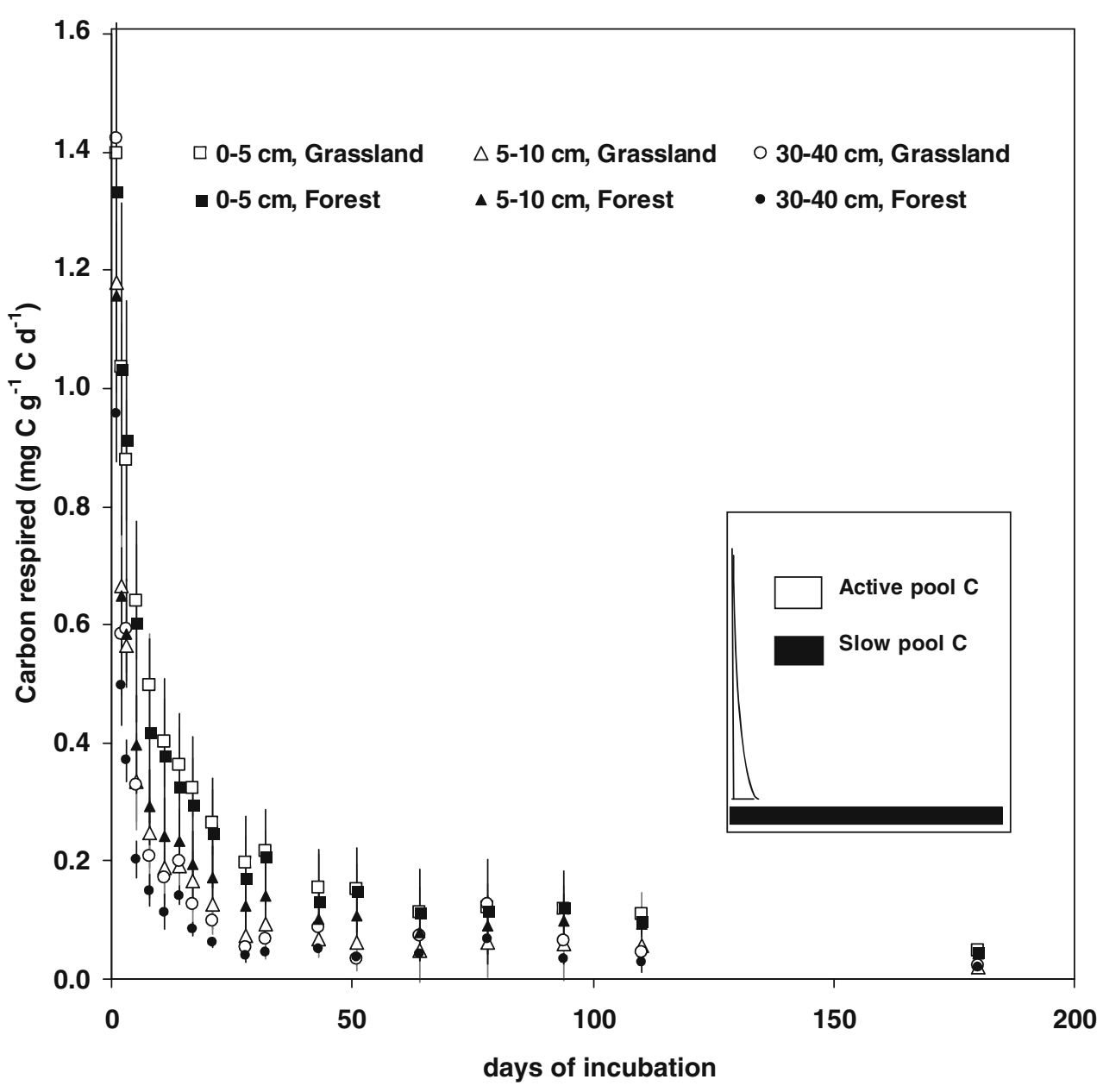

significantly higher proportion of grassland SOC (32\%) Isotopic composition than of forest SOC (27\%; Table 3).

Removing low-density organic debris by density fractionation before hydrolysis tended to result in a lower proportion of NHC in 0 - to 5- and 5- to 10-cm depth under forest. Under grassland $(0-5 \mathrm{~cm})$ pretreatment of samples led to a significant decrease of NHC (Table 3).

The total $\mathrm{C}$ (no pretreatment) $\delta^{13} \mathrm{C}$ signature differed significantly between forest $(-25.0$ to $-28.0 \%$ ) and grassland $(-21.4$ to $-23.5 \%$; Table 4$)$ because the forest was dominated by $\mathrm{C}_{3}$ trees (forest litter $=-30.1 \pm 0.5 \%$ ), and the grassland was dominated by $\mathrm{C}_{4}$ grasses (grass residue $=-16.2 \pm 4.2 \%$ ).

Table 1 Total C content and cumulative amount of mineralized C from forest and grassland soil after 180 days of incubation, Barro Colorado Island, Panama (values in parentheses are \pm 1 standard deviation, $n=3$ )

\begin{tabular}{|c|c|c|c|c|c|}
\hline \multirow[t]{2}{*}{ Site } & \multirow{2}{*}{$\begin{array}{l}\text { Depth } \\
(\mathrm{cm})\end{array}$} & \multirow{2}{*}{$\begin{array}{l}\text { Total C } \\
\left(\mathrm{g} \mathrm{C} \mathrm{kg}^{-1}\right)\end{array}$} & \multicolumn{3}{|l|}{ Mineralized C } \\
\hline & & & $\begin{array}{l}\text { Soil basis } \\
\text { ( } \mu \mathrm{g} \mathrm{C} \mathrm{g}^{-1} \text { soil per } 180 \text { days) }\end{array}$ & $\begin{array}{l}\mathrm{C} \text { basis } \\
\text { (mg C g }{ }^{-1} \mathrm{C} \text { per } 180 \text { days) }\end{array}$ & $\begin{array}{l}\text { Percent of } \\
\text { total C }(\%)\end{array}$ \\
\hline \multirow[t]{3}{*}{ Forest } & $0-5$ & 44.7 a A (14.1) & 1151 a A (479) & 28.5 a A (14.4) & 2.6 a $\mathrm{A}(0.8)$ \\
\hline & $5-10$ & 23.5 b A (4.7) & 480 a A (196) & 21.3 a $\mathrm{A}(8.5)$ & 2.0 a $\mathrm{A}(1.0)$ \\
\hline & $30-40$ & 8.9 с A (1.6) & 84 b A (20) & 10.2 b A (2.4) & 0.9 b A $(0.4)$ \\
\hline \multirow[t]{3}{*}{ Grassland } & $0-5$ & 38.2 a $\mathrm{A}(6.9)$ & 1130 a A (299) & 28.1 a $\mathrm{A}(7.1)$ & 2.9 a A (1.1) \\
\hline & $5-10$ & 27.3 b A (1.7) & 424 a A (275) & 15.2 a $\mathrm{A}(8.8)$ & $1.6 \mathrm{ab} \mathrm{A}(0.8)$ \\
\hline & $30-40$ & 5.2 с B $(0.9)$ & 80 b A (20) & $16.0 \mathrm{~b} \mathrm{~A}(4.1)$ & 1.5 b B $(0.2)$ \\
\hline
\end{tabular}

Different small letters indicate differences among depths for each land-cover type; different capital letters indicate differences between land-cover types for that depth $(P<0.05)$. 
Table 2 Pool sizes and mean residence times (MRT) determined from long-term incubation of forest and grassland soil from 0- to 5-, 5- to 10-, and 30- to 40-cm depths, Barro Colorado Island, Panama (values in parentheses are \pm 1 standard deviation, $n=3$ )

\begin{tabular}{|c|c|c|c|c|c|c|}
\hline \multirow[t]{2}{*}{ Site } & \multirow[t]{2}{*}{ Depth $(\mathrm{cm})$} & \multirow[t]{2}{*}{ Total C $\left(\mathrm{g} \mathrm{C} \mathrm{kg}^{-1}\right)$} & \multicolumn{2}{|l|}{ Active $\mathrm{C}$} & \multicolumn{2}{|l|}{ Slow $\mathrm{C}^{\mathrm{a}}$} \\
\hline & & & $\%$ of total $\mathrm{C}$ & MRT days & $\%$ of total $\mathrm{C}$ & MRT years \\
\hline \multirow[t]{3}{*}{ Forest } & $0-5$ & 44.7 a A (14.1) & 0.7 a A (0.2) & 5.9 a A (1.3) & 36.2 a A (3.3) & 14.7 a A (3.1) \\
\hline & $5-10$ & 23.5 b A (4.7) & $0.4 \mathrm{~b} \mathrm{~A}(0.1)$ & 3.2 b A (1.0) & 42.7 a A (3.0) & 16.3 a A (5.4) \\
\hline & $30-40$ & 8.9 с A (1.6) & 0.3 с A $(0.1)$ & $2.0 \mathrm{~b} \mathrm{~A}(0.5)$ & 72.4 b A (5.8) & $53.2 \mathrm{~b} \mathrm{~A}(6.1)$ \\
\hline \multirow[t]{3}{*}{ Grassland } & $0-5$ & 38.2 a A (6.9) & 0.9 a $\mathrm{A}(0.1)$ & 6.4 a A (1.8) & 35.1 a A (4.7) & 11.7 a A (2.2) \\
\hline & $5-10$ & 27.3 b A (1.7) & $0.4 \mathrm{~b} \mathrm{~A}(0.1)$ & 2.9 b A (0.9) & 46.0 a $\mathrm{A}(3.0)$ & $22.3 \mathrm{~b} \mathrm{~A}(8.3)$ \\
\hline & $30-40$ & 5.2 с B (0.9) & 0.4 b B $(0.2)$ & 1.7 b A (0.1) & 67.1 b A (6.1) & 29.4 b B (4.1) \\
\hline
\end{tabular}

Different small letters indicate differences among depths for each land-use type; different capital letters indicate differences between land-use types for that depth $(P<0.05)$.

${ }^{a}$ Slow $\mathrm{C}=$ total $\mathrm{C}-$ active pool $\mathrm{C}-$ non-hydrolysable $\mathrm{C}$ (pretreated)

The $\delta^{13} \mathrm{C}$ values of forest and grassland soil did not change significantly during the incubation (Table 4). All samples that were subjected to density fractionation (pretreatment) were slightly more enriched in ${ }^{13} \mathrm{C}$ as compared to samples without removal of organic debris (Table 4). Pretreatment slightly reduced the proportion of new $\mathrm{C}$ and increased the MRT in subsoil (Table 3).

Independent of pretreatment and vegetation type, the $\delta^{13} \mathrm{C}$ value of $\mathrm{NHC}$ residue was more negative than total $\mathrm{C}$ (Table 4). The $\delta^{13} \mathrm{C}$ values of total $\mathrm{C}$ and $\mathrm{NHC}$ became more positive with depth in the forest but more negative in the grassland (Table 4). The proportion of $\mathrm{C}_{4}$ derived NHC under grassland was $46 \%$ in $0-5 \mathrm{~cm}$ and $17 \%$ in $30-40 \mathrm{~cm}$ (Table 3). The MRT of NHC ranged between 120 years $(0$ $5 \mathrm{~cm})$ and 318 years $(30-40 \mathrm{~cm}$; Table 3$)$.

The $\delta^{13} \mathrm{C}$ signatures of respired $\mathrm{CO}_{2}$ reflect the $\mathrm{C}$ substrates utilized during active and slow pool phases of the incubation (Fig. 2). The $\delta^{13} \mathrm{C}$ respired from active pool $\mathrm{C}$ (corrected for the contribution of slow pool $\delta^{13} \mathrm{C}$ ) was
$-18.2 \pm 1.4 \%$ under grassland and $-24.2 \pm 3.9 \%$ under forest. Slow pool C $(-27.2 \pm 1.1 \%)$ under forest was slightly more negative than active pool $\mathrm{C}(P>0.05)$, whereas under grassland, slow pool C $(-16.2 \pm 2.4 \%)$ was similar to active pool $\mathrm{C}(P>0.05)$. In the grassland, the $\mathrm{CO}_{2}$ respired from the active- and slow-pool $\mathrm{C}$ was derived primarily ( $>80 \%$ ) from the actual $\mathrm{C}_{4}$ vegetation (Eq. 3).

\section{Discussion}

Pools and kinetics of carbon decomposition

Under both land-cover types, the proportion of active pool $\mathrm{C}$ was small $(<1 \%)$ and MRTs were short $(\sim 10$ days $)$, leading to rejection of our first hypothesis that active pool size and its MRT would be most affected by the conversion from forest to grassland. Forest and grassland soil apparently did not differ considerably with respect to their labile
Table 3 Fraction of non-hydrolysable carbon (NHC) of forest and grassland soil, proportion of new $\mathrm{NHC}$, and mean residence time (MRT) of NHC in grassland soil (no pretreatment vs. pretreatment to remove light fraction organic matter) of from 0 - to 5-, 5- to 10 - and 30to $40-\mathrm{cm}$ depths, Barro Colorado Island, Panama (values in parentheses are \pm 1 standard deviation)

\begin{tabular}{|c|c|c|c|c|c|c|c|c|c|}
\hline \multirow[t]{3}{*}{ Site } & \multirow[t]{3}{*}{ Depth $(\mathrm{cm})$} & \multicolumn{4}{|l|}{ No pretreatment } & \multicolumn{4}{|l|}{ Pretreatment } \\
\hline & & \multicolumn{2}{|l|}{$\mathrm{NHC}$} & \multirow{2}{*}{$\frac{\mathrm{NHC}_{\text {new }}}{\%}$} & \multirow{2}{*}{$\frac{\text { MRT }}{\text { Years }}$} & \multicolumn{2}{|l|}{$\mathrm{NHC}$} & \multirow{2}{*}{$\frac{\mathrm{NHC}_{\text {new }}}{\%}$} & \multirow{2}{*}{$\frac{\text { MRT }}{\text { years }}$} \\
\hline & & $\mathrm{g} \mathrm{C} \mathrm{kg}^{-1}$ & $\%$ of total $\mathrm{C}$ & & & $\mathrm{g} \mathrm{C} \mathrm{kg}^{-1}$ & $\%$ of total C & & \\
\hline \multirow[t]{3}{*}{ Forest } & $0-5$ & 27.8 a $\mathrm{A}(5.2)$ & $63.1 \mathrm{a} \mathrm{A}^{1}(3.8)$ & & & $21.0 \mathrm{~A}(2.3)$ & $57.8^{1}(6.6)$ & & \\
\hline & $5-10$ & 16.7 a A (3.3) & 56.9 a $\mathrm{A}(5.2)$ & & & $10.5(-)$ & $39.8(-)$ & & \\
\hline & $30-40$ & $2.8 \mathrm{~b} \mathrm{~A}(1.0)$ & 27.3 b A (1.7) & & & $2.5(-)$ & $27.0(-)$ & & \\
\hline \multirow[t]{3}{*}{ Grassland } & $0-5$ & 24.5 a $\mathrm{A}(4.0)$ & 64.0 a $\mathrm{A}^{1}(5.2)$ & 46.4 & 119.6 & $19.2 \mathrm{~A}(1.1)$ & $54.0^{2}(2.6)$ & 46.3 & 122.5 \\
\hline & $5-10$ & 15.8 a $\mathrm{A}(2.3)$ & $53.6 \mathrm{~b}$ A (3.5) & 32.1 & 260.3 & $17.3(-)$ & $53.8(-)$ & 37.3 & No data \\
\hline & $30-40$ & 2.6 b A (0.9) & 32.5 c B $(0.7)$ & 17.0 & 317.7 & $2.3(-)$ & $32.4(-)$ & 12.0 & 508.9 \\
\hline
\end{tabular}

Different small letters indicate differences among depths for each land-use type; different capital letters indicate differences between land-use types for that depth; significant differences between NHC (no pretreatment vs. pretreatment) are denoted by different numbers $(P<0.05)$. 
Table $4 \delta^{13} \mathrm{C}$ values of total $\mathrm{C}$ and non-hydrolysable carbon (NHC) of forest and grassland soil from 0- to 5-, 5- to 10-, and 30- to 40-cm depths, Barro Colorado Island, Panama (values in parentheses are \pm 1 standard deviation, $n=3$ )

\begin{tabular}{|c|c|c|c|c|c|c|}
\hline \multirow[t]{2}{*}{ Site } & \multirow[t]{2}{*}{ Depth $(\mathrm{cm})$} & \multicolumn{3}{|l|}{ Total C } & \multicolumn{2}{|l|}{ NHC } \\
\hline & & No pretreatment & Pretreatment & After incubation, $\delta^{13} \mathrm{C}(\%)$ & No pretreatment & Pretreatment \\
\hline \multirow[t]{3}{*}{ Forest } & $0-5$ & $-28.0 \mathrm{a} \mathrm{A}^{1}(0.5)$ & $-25.9 \mathrm{~A}^{2}(0.9)$ & $-27.2 \mathrm{a} \mathrm{A}^{1,2}(0.3)$ & $-30.0 \mathrm{a} \mathrm{A}^{3}(0.4)$ & $-29.6 \mathrm{~A}^{3}(0.7)$ \\
\hline & $5-10$ & -26.9 a b A $A^{1}(0.6)$ & $-25.0(-)$ & -26.1 a A $^{1}(0.4)$ & $-29.1 \mathrm{ab} \mathrm{A} \mathrm{A}^{1}(1.4)$ & $-29.4(-)$ \\
\hline & $30-40$ & $-25.0 \mathrm{~b} \mathrm{~A}^{1}(0.1)$ & $-23.0(-)$ & $-24.8 \mathrm{~b} \mathrm{~A}^{1}(0.7)$ & $-26.0 \mathrm{~b} \mathrm{~A}^{2}(0.2)$ & No data \\
\hline \multirow[t]{3}{*}{ Grassland } & $0-5$ & -21.4 a B $^{1}(0.9)$ & $-20.3 \mathrm{~B}^{1}(0.3)$ & -21.9 a $\mathrm{B}^{1}(0.9)$ & -23.5 a $\mathrm{B}^{1}(1.1)$ & -23.3 a $^{1}(0.1)$ \\
\hline & $5-10$ & $-22.4 \mathrm{a} \mathrm{B}^{1}(0.8)$ & $-21.6(-)$ & -22.7 a $B^{1}(1.2)$ & -24.9 a $\mathrm{B}^{2}(0.7)$ & $-24.4(-)$ \\
\hline & $30-40$ & $-23.5 \mathrm{~b} \mathrm{~B}^{1}(0.6)$ & $-23.0(-)$ & $-22.4 \mathrm{a} \mathrm{A}^{1}(1.4)$ & -24.3 a B $^{2}(0.1)$ & $-24.8(-)$ \\
\hline
\end{tabular}

Different small letters indicate differences among depths for each land-use type; different capital letters indicate differences between land-use types for that depth; significant differences between values in rows are denoted by different numbers $(P<0.05)$.

pool substrate quality. Active pool $\mathrm{C}$ may have been comprised mainly of metabolic cell contents that did not differ in quality between the vegetation types.

Our results on the proportion of active pool $\mathrm{C}(<1 \%$, Table 2) were on the low end of most reported values $(0.5-$ $8 \%$ ) from long-term incubation studies on temperate and tropical forest and grassland soils (Townsend et al. 1997; Haile-Mariam et al. 2000; Torn et al. 2005). At a 50-year-old pasture site approximately $40 \mathrm{~km}$ east of the study area, active pool carbon was $1.2 \%$ of $C_{\mathrm{t}}$ (Schwendenmann et al. 2007). Differences in active pool $C$ sizes among sites may be attributable to soil clay content. Gregorich et al. (1991), Ladd et al. (1996), and Franzluebbers (1999) observed a positive correlation between clay content and microbial biomass. Although the clay content of our soils was considerable $(\sim 30 \%)$, active pool size was low. This is in agreement with Torn et al. (2005) who did not find a correlation between soil texture, carbon pool sizes, and turnover times in Hawaiian soils of different soil mineralogy.
Active pool C MRTs of the studied forest and grassland surface soils were shorter than values reported in other studies (Paul et al. 2006). The data compiled by Paul et al. (2006) are from temperate grassland soils. Šantrůčkowá et al. (2000) compared microbial processes in tropical and temperate grassland soils, and reported that the turnover rate of organic material may be faster in tropical soils as compared to temperate soils. The MRTs between 2 and 6 days found in our experiment can be compared with MRTs of glucose (1 day) and fungal cytoplasm (10 days; Paul and Clark 1996).

The MRT of active pool $\mathrm{C}$ decreased significantly with depth under grassland and forest. The MRT of active $\mathrm{C}$ under grassland tended to be lower, whereas the percentage of total $\mathrm{C}$ mineralized in subsoil was significantly higher under grassland $(1.5 \%)$ than forest $(0.9 \%)$. This reinforces that $\mathrm{C}$ in grassland at depth is more labile than in forest. A larger contribution of roots and root exudates may explain the more labile nature of $\mathrm{C}$ at depth in grassland soil. It is unlikely that sampling disturbance would explain shorter MRTs in deeper
Fig. 2 The $\delta^{13} \mathrm{C}$ signature of $\mathrm{CO}_{2}$ respired for forest and grassland soil $(0-5 \mathrm{~cm})$, Barro Colorado Island, Panama. Error bars are \pm 1 standard deviation, $n=3$

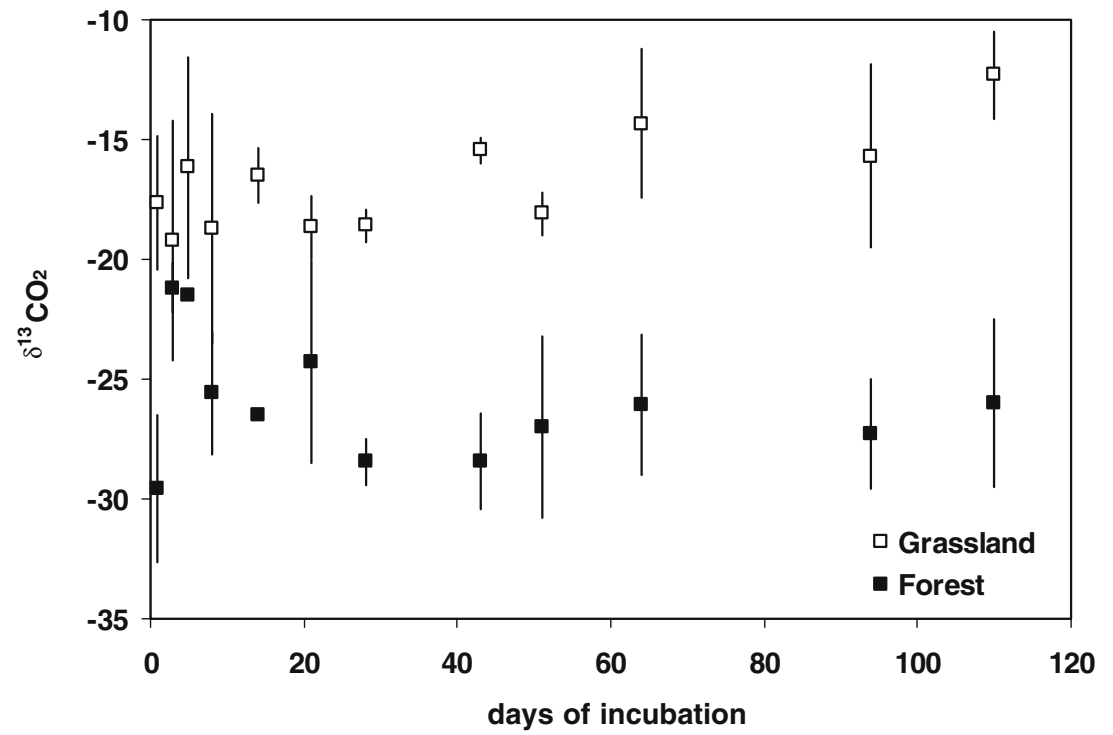


layers (Ewing et al. 2007) as the soil under forest and grassland mainly consisted $(60 \%$ to $80 \%)$ of small macroaggregates (250-2,000 $\mu \mathrm{m}$; Schwendenmann and Pendall 2006), which were not disturbed by using a large sieve.

The MRTs of slow pool C in the top $10 \mathrm{~cm}$ of the forest were similar to slow pool C MRTs estimated in other moist tropical forests. Soil incubations revealed that the slow pool of Andisols in Hawaiian pastures and forests had MRTs of 4-20 years (Townsend et al. 1995; Torn et al. 2005). Near Manaus, Brazil, the slow pool C had MRTs of 5-10 years (Telles et al. 2003), as estimated through radiocarbon data. Our hypothesis that slow pool C would be less affected by vegetation change was supported for upper soil layers, as slow pool MRT did not differ significantly between forest and grassland.

However, the slow pool MRT was significantly shorter in grassland (29 years) than forest subsoil (53 years), possibly because substrate quality and root exudation were higher in grassland at that depth. Fontaine et al. (2007) suggest that priming by the input of fresh-plant-derived carbon to the subsoil can increase decomposition of deeper soil C. Faster slow pool turnover of grassland SOC in deeper layers is consistent with significantly lower total SOC concentration in grassland subsoil (Table 1), especially considering that $70 \%$ of the total pool is slow $\mathrm{C}$ in subsoil.

\section{Non-hydrolysable carbon}

There is increasing concern about the suitability of $\mathrm{HCl}$ hydrolysis to isolate older $\mathrm{C}$ fractions because fresh plant material can resist hydrolysis, whereas older $\mathrm{C}$ components, possibly stabilized by mineral association, may be selectively hydrolyzed (Balsesdent 1996; Helfrich et al. 2007). The NHC expressed as a percentage of total $\mathrm{C}$ varied between $54 \%$ and $64 \%$ in the surface soil $(0-5 \mathrm{~cm})$ and decreased with depth to $\sim 30 \%$ at $30-40 \mathrm{~cm}$. Removing organic debris by density fractionation before hydrolysis tended to slightly reduce the fraction of NHC. In pretreated samples, Plante et al. (2006b) found in $0-5 \mathrm{~cm}$ depth a NHC proportion of 32$50 \%$ under native grassland in Saskatchewan and 41-55\% from soil developed under forest in Ohio. A recent review based on the analysis of over 300 data points (forest, grassland, and cultivated soils; 0 - to $10-\mathrm{cm}$ depths) showed that the $\mathrm{C}$ remaining after hydrolysis with $6-\mathrm{M} \mathrm{HCl}$ (at $116^{\circ} \mathrm{C}$ ) ranged from $30 \%$ to $80 \%$ of the total $\mathrm{C}$ (Paul et al. 2006).

In both forest and grassland soils, NHC decreased with depth. This was also reported by Paul et al. (2006) for cultivated conventional tillage and forested sites from different climatic regions. We found that the proportion of $\mathrm{NHC}$ was strongly correlated to the amount of total C (grassland, $r^{2}=0.91$; forest, $r^{2}=0.84$ ). Plante et al. (2006a) also observed a strong correlation of $\mathrm{C}$ concentrations in the $\mathrm{NHC}$ fraction with total $\mathrm{C}$ content. This relationship might partly explain the differences in $\mathrm{NHC}$ between surface soil and subsoil.

Forest NHC had more negative $\delta^{13} \mathrm{C}$ values than total $\mathrm{C}$, suggesting that the 6-M $\mathrm{HCl}$ digest method concentrates lignin and/or lipids (alkyl-C) relative to the bulk soil (Preston et al. 1997; Plante et al. 2006a) because both these constituents are depleted in ${ }^{13} \mathrm{C}$ relative to whole plant tissue (Benner et al. 1987). The isotopic signature of NHC under forest $(-29.6 \pm 0.70 \%$ to $-30.0 \pm 0.38 \%$ o was similar to free light fraction $\left(<1.85 \mathrm{~g} \mathrm{~cm}^{-3} ;-29.2\right.$ to $-31.3 \%$; Schwendenmann and Pendall 2006), also supporting the idea that NHC contains recently deposited plant material. Under grassland, alkyl-C left after biomass burning may contribute a sizable fraction of grassland NHC due to its recalcitrant nature (Lorenz et al. 2007). Alternatively, the more negative $\delta^{13} \mathrm{C}$ signal of grassland $\mathrm{NHC}$ as compared to total $\mathrm{C}$ could indicate that grassland $\mathrm{NHC}$ still contains a considerable amount of forest-derived $\mathrm{C}$, which agrees with the longer MRT of grassland NHC. Our data indicate that MRT of grassland NHC (120 to 320 years, no pretreatment) is considerably longer than slow pool C (12 to 29 years by the incubation method) and bulk soil C (70 to 190 years by the ${ }^{13} \mathrm{C}$ method; Schwendenmann and Pendall 2006). The MRT data and the relatively small change observed with pretreatment support the idea that the hydrolysis residue is distinctly older than the slow pool and largely derived from forest $\mathrm{C}$.

In the upper $10 \mathrm{~cm}$, we did not observe a significant difference between forest and grassland with respect to the proportion of NHC. In contrast, the proportion of NHC at 30 $40 \mathrm{~cm}$ depth was significantly higher under grassland as compared to forest (Table 3). This observation has to be treated with care as our data set is small. Nonetheless, our results are in agreement with Parton et al. (1987) who suggest that resistant pool $\mathrm{C}$ should be a greater proportion of the total $\mathrm{C}$ under pasture or cultivated land as a result of a loss of active and slow pool $\mathrm{C}$ due to enhanced mineralization caused by land-use change. Our results demonstrate that acid hydrolysis after density fractionation can result in an old $\mathrm{C}$ pool, but more detailed structural analysis such as with ${ }^{13} \mathrm{C}$-NMR would provide further insight into the nature of the resistant soil C pool (Nelson and Baldock 2005).

\section{Changes of $\delta^{13} \mathrm{C}$ during decomposition}

We expected differences in $\delta^{13} \mathrm{C}$ among carbon pools that would allow us to gain information on decomposition dynamics. Respired $\mathrm{CO}_{2}$ from forest soil was more enriched in ${ }^{13} \mathrm{C}$ than total $\mathrm{C}$ (before incubation) and plant residue (Table 4, Fig. 2). We suggest that this might be caused by selective utilization of ${ }^{13} \mathrm{C}$-enriched compounds, such as carbohydrates or polysaccharides (Gleixner et al. 1999). Furthermore, the active pool consists mainly of microbial 
matter, which is enriched in ${ }^{13} \mathrm{C}$ (Werth and Kuzyakov 2008). It is unlikely that isotopic discrimination accompanying heterotrophic metabolism (Šantrůčkowá et al. 2000) explained this pattern, in part because the continuous loss of ${ }^{13} \mathrm{C}$-enriched compounds during incubation did not result in

${ }^{13} \mathrm{C}$-depletion in soil $\mathrm{C}$ (after incubation).

In the grassland, $\mathrm{CO}_{2}$ respired throughout the incubation was almost entirely $\mathrm{C}_{4}$-derived (>80\%). As the conversion from forest to grassland took place 90 years ago, the forestderived mineralizable $\mathrm{C}$ in 0 - to 5 -cm depth was nearly all replaced by grassland $\mathrm{C}$. We expected to observe a decrease in $\delta^{13} \mathrm{C}$ values of respired $\mathrm{CO}_{2}$ concurrently with the drop in mineralization rates as evidence that some forest $\mathrm{C}$ remained in the slow pool. Instead, the microbial respiration in both grassland and forest soils appeared to be close to equilibrium with the current vegetation at each site during both the active and slow pool phases.

\section{Evaluation of methods}

Laboratory incubation combined with acid hydrolysis was applied to quantify and characterize active, slow, and passive soil C pools. Non-linear curve fitting analysis after Paul et al. (2001) provided reasonable results for active pool size and the active and slow pool mean residence times. Slow pool C is defined as the difference between total $\mathrm{C}$ and the sum of active $\mathrm{C}$ and the $\mathrm{C}$ found in the acid hydrolysis residue (NHC). Thus, slow pool $\mathrm{C}$ and its respective mean residence time are also influenced by the magnitude of the NHC pool. With acid hydrolysis, we were able to isolate an older $\mathrm{C}$ fraction, which in the case of the grassland, also contains a larger fraction of the previous forest vegetation. It remains questionable if the 6-M HCl extraction method is appropriate to quantifying resistant pool $\mathrm{C}$ in part because pretreatment to remove light fraction material had inconsistent effects on NHC content and its $\delta^{13} \mathrm{C}$ and MRT. Thus, slow pool $\mathrm{C}$ and its turnover rates have to be interpreted carefully.

Although laboratory incubation has some shortcomings, it is one of the few methods providing insight into active and slow pool $\mathrm{C}$ dynamics. In an earlier study, we used physical fractionation (separation of water stable aggregates and density fractions) coupled with carbon isotope techniques to assess carbon pools and mean residence times of the same soils (Schwendenmann and Pendall 2006). The MRT of grassland bulk soil $\mathrm{C}$ was considerably longer (70 years in $0-5 \mathrm{~cm}$ and 190 years in 30-40 cm; Schwendenmann and Pendall 2006) as compared to slow pool MRT estimated by incubation-acid hydrolysis method. Intra-aggregate particulate organic matter of grassland soil had MRT (29-50 years for the top $10 \mathrm{~cm}$; Schwendenmann and Pendall 2006) closest to the MRT estimated for slow pool $\mathrm{C}$ in the present experiment. Using physical, chemical, and biological fractionation techniques produced obviously distinct $\mathrm{C}$ pools as demonstrated by their different MRTs. However, von Lützow et al. (2007) warn that most methods still yield C pools, which are heterogeneous in terms of turnover times.

These results imply that increased conversion of tropical forests to grassland vegetation can lead to substantial losses of belowground C. Recent evidence that terrestrial C sinks are becoming weaker in recent years (Canadell et al. 2007) could be partly explained by decadal scale responses of $\mathrm{C}$ cycling to twentieth-century land-use change.

Acknowledgment The authors thank Marco Valdez, Brandy Cline, and Ian Abernethy for their field and laboratory assistance. Thanks to Robert F. Stallard for introducing us to the study sites. We thank Mark Larson for his help with the stable $\mathrm{C}$ isotope analysis. Helpful comments on the manuscript were provided by two anonymous reviewers. This research was supported by the Smithsonian Tropical Research Institute, Wyoming NASA Space Grant Consortium, NASA Grant \#NGT-40102, Wyoming NASA EPSCoR, NASA grant no. NCC5-578, and an International Travel Grant from the University of Wyoming to E. Pendall.

Open Access This article is distributed under the terms of the Creative Commons Attribution Noncommercial License which permits any noncommercial use, distribution, and reproduction in any medium, provided the original author(s) and source are credited.

\section{References}

Balesdent J (1996) The significance of organic separates to carbon dynamics and its modeling in some cultivated soils. Eur J Soil Sci 47:485-494

Balesdent J, Mariotti A (1996) Measurement of soil organic matter turnover using ${ }^{13} \mathrm{C}$ natural abundance. In: Boutton TW, Yamasaki $\mathrm{S}$ (eds) Mass spectrometry of soils. Marcel Dekker, New York, pp 83-112

Benner R, Fogel ML, Sprague EK, Hodson RE (1987) Depletion of ${ }^{13} \mathrm{C}$ in lignin and its implications for stable carbon isotope studies. Nature 329:708-710

Canadell JG, LeQuere C, Raupach MR, Field CB, Buitenhuis ET, Ciais P, Conway TJ, Gillett NP, Houghton RA, Marland G (2007) Contributions to accelerating atmospheric $\mathrm{CO}_{2}$ growth from economic activity, carbon intensity, and efficiency of natural sinks. P Natl Acad Sci USA 104:18866-18870

Condit R, Windsor DM, Hubbell SP (1996) NPP tropical forest: Barro Colorado, Panama, 1969-1990. Data set from Oak Ridge National Laboratory Distributed Active Archive Center, Oak Ridge, Tennessee, USA. http://www.daac.ornl.gov

Condit R, Robinson WD, Ibanez DS, Aguilar S, Sanjur A, Martinez R, Stallard RF, Garcia T, Angehr GR, Petit L, Wright SJ, Robinson TR, Heckadon-Moreno S (2001) The status of the Panama Canal watershed and its biodiversity at the beginning of the 21st century. BioScience 51:135-144

Ewing SA, Sanderman J, Baisden WT, Wang Y, Amundson R (2007) Role of large-scale soil structure in organic carbon turnover: evidence from California grassland soils. J Geophys Res 111:G03012

Fierer N, Allen AS, Schimel JP, Holden PA (2003) Controls on microbial $\mathrm{CO}_{2}$ production: a comparison of surface and subsurface horizons. Glob Change Biol 9:1322-1332 
Fontaine S, Barot S, Barre P, Bdioui N, Mary B, Rumpel C (2007) Stability of organic carbon in deep soil layers controlled by fresh carbon supply. Nature 450:277-280

Franzluebbers AJ (1999) Potential C and N mineralization and microbial biomass from intact and increasingly disturbed soil of varying texture. Soil Biol Biochem 31:1083-1090

Gleixner G, Bol R, Balesdent J (1999) Molecular insight into soil carbon turnover. Rapid Commun Mass Spectrom 13:1278-1283

Gregorich EG, Voroney RP, Kachanosk RG (1991) Turnover of carbon through the microbial biomass in soil with different textures. Soil Biol Biochem 23:799-805

Haile-Mariam S, Cheng W, Johnson DW, Ball JT, Paul EA (2000) Use of carbon-13 and carbon-14 to measure the effects of carbon dioxide and nitrogen fertilization on carbon dynamics in ponderosa pine. Soil Sci Soc Am J 64:1984-1993

Helfrich M, Flessa H, Mikutta R, Dreves A, Ludwig B (2007) Comparison of chemical fractionation methods for isolating stable soil organic carbon pools. Eur J Soil Sci 58:1316-1329

Kögel-Knabner I, de Leeuw JW, Tegekaar EW, Hatcher PG, Kerp H (1994) A lignin-like polymer in the cuticle of spruce needles: implications for humification of spruce litter. Org Geochem 21:1219-1228

Ladd JN, Forster RC, Nannipieri P, Oades JM (1996) Soil structure and biological activity. In: Stotzky G, Bollag JM (ed) Soil biochemistry, vol. 9. Marcel Dekker, New York, pp 23-78

Leavitt S, Follet RF, Paul EA (1996) Estimation of slow and fast cycling soil organic carbon pools from $6 \mathrm{~N} \mathrm{HCl}$ hydrolysis. Radiocarbon 38:231-239

Leigh EG Jr, Rand AS, Windsor DM (1996) The ecology of a tropical forest: seasonal rhythms and long-term changes. Smithsonian Institution Press, Washington, DC

Lorenz K, Lal R, Preston CM, Nierop KGJ (2007) Strengthening the soil organic carbon pool by increasing contributions from recalcitrant aliphatic bio(macro)molecules. Geoderma 142:1-10

McLauchlan KK, Hobbie SE (2004) Comparison of labile soil organic matter fractionation techniques. Soil Sci Soc Am J 68:1616-1625

Nelson PN, Baldock JA (2005) Estimating the molecular composition of a diverse range of natural organic materials from solid-state ${ }^{13} \mathrm{C}$ NMR and elemental analyses. Biogeochemistry 72:1-34

Parton WJ, Schimel DS, Cole CV, Ojima DS (1987) Analysis of factors controlling soil organic matter levels in Great Plains grasslands. Soil Sci Soc Am J 51:1173-1179

Paul EA, Clark FE (1996) Soil microbiology and biochemistry. Academic, San Diego

Paul EA, Morris SJ, Bohm S (2001) The determination of soil C pool sizes and turnover rates: biophysical fractionation and tracers. In: Lal R, Kimble JM, Follett RF, Stewart BA (eds) Assessment methods for soil carbon. Lewis, Boca Raton, pp 193-206

Paul EA, Morris SJ, Conant RT, Plante AF (2006) Does the acid hydrolysis-incubation method measure meaningful soil organic carbon pools? Soil Sci Soc Am J 70:1023-1035

Pendall E, King JY (2007) Soil organic matter dynamics in grassland soils under elevated $\mathrm{CO}_{2}$ : insights from long-term incubations and stable isotopes. Soil Biol Biochem 39:2628-2639

Plante AF, Conant RT, Paul EA, Paustian K, Six J (2006a) Acid hydrolysis of easily dispersed and microaggregate-derived soiland clay-sized fractions to isolate resistant soil organic matter. Eur J Soil Sci 57:456-467

Plante AF, Conant RT, Stewart CE, Paustian K, Six J (2006b) Impact of soil texture on the distribution of soil organic matter in physical and chemical fractions. Soil Sci Soc Am J 70:287-296

Poirier N, Derenne S, Balesdent J, Chenu C, Bardoux G, Mariotti A, Largeau C (2006) Dynamics and origin of the non-hydrolysable organic fraction in a forest and a cultivated temperate soil, as determined by isotopic and microscopic studies. Eur J Soil Sci 57:719-730
Preston CM, Trofymow JA, Sayer BG, Niu JN (1997) ${ }^{13}$ C nuclear magnetic resonance spectroscopy with cross-polarization and magic-angle spinning investigation of the proximate-analysis fractions used to assess litter quality in decomposition studies. Can J Bot 75:1601-1613

Šantrůčkowá H, Bird MI, Lloyd L (2000) Microbial processes and carbon-isotope fractionation in tropical and temperate grassland soils. Funct Ecol 14:108-114

Schwendenmann L, Pendall E (2006) Effects of forest conversion into grassland on soil aggregate structure and carbon storage in Panama: evidence from soil carbon fractionation and stable isotopes. Plant Soil 288:217-232

Schwendenmann L, Veldkamp E, Brenes T, O’Brien JJ, Mackensen J (2003) Spatial and temporal variation in soil $\mathrm{CO}_{2}$ efflux in an old-growth neotropical rain forest, La Selva, Costa Rica. Biogeochemistry 64:111-128

Schwendenmann L, Pendall E, Potvin C (2007) Surface soil organic carbon pools, mineralization and $\mathrm{CO}_{2}$ efflux rates under different land-use types in Central Panama. In: Tscharntke T, Leuschner C, Zeller M, Guhardja E, Bidin A (eds) The stability of tropical rainforest margins: linking ecological, economic and social constraints of land use and conservation. Springer-Verlag, Berlin Heidelberg New York, pp 109-131

Six J, Jastrow JD (2002) Soil organic matter turnover. In: Lal R (ed) Encyclopedia of soil science. Marcel Dekker, New York, pp 936-942

Six J, Conant RT, Paul EA, Paustian K (2002) Stabilization mechanisms of soil organic matter: implications for $\mathrm{C}$-saturation of soils. Plant Soil 241:155-176

Smith BN, Epstein S (1971) Two categories of ${ }^{13} \mathrm{C} /{ }^{12} \mathrm{C}$ ratios for higher plants. Plant Physiol 47:380-384

STRI (2006) BCI climate summary. Terrestrial-Environmental Sciences Program of the Smithsonian Tropical Research Institute. http://striweb.si.edu/esp/physical monitoring/summary bci.htm

Telles EDC, de Camargo PB, Martinelli LA, Trumbore SE, da Costa ES, Santos J, Higuchi N, Oliveira RC (2003) Influence of soil texture on carbon dynamics and storage potential in tropical forest soils of Amazonia. Glob Biogeochem Cycles 17:1040

Torn MS, Vitousek PM, Trumbore SE (2005) The influence of nutrient availability on soil organic matter turnover estimated by incubations and radiocarbon modeling. Ecosystems 8:352-372

Townsend AR, Vitousek PM, Trumbore SE (1995) Soil organic matter dynamics along gradients in temperature and land-use. Ecology 76:721-733

Townsend AR, Vitousek PM, Desmarais DJ, Tharpe A (1997) Soil carbon pool structure and temperature sensitivity inferred using $\mathrm{CO}_{2}$ and ${ }^{13} \mathrm{CO}_{2}$ incubation fluxes from five Hawaiian soils. Biogeochemistry 38:1-17

Trumbore SE (1997) Potential responses of soil organic carbon to global environmental change. P Natl Acad Sci USA 94:8284-8291

Trumbore SE, Zheng S (1996) Comparison of fractionation methods for soil organic matter ${ }^{14} \mathrm{C}$ analysis. Radiocarbon 38:219-229

Von Lützow M, Kögel-Knabner I, Ekschmitt K, Matzner E, Guggenberger G, Marschner B, Flessa H (2006) Stabilization of organic matter in temperate soils: mechanisms and their relevance under different soil conditions - a review. Eur J Soil Sci 57:426-445

Von Lützow M, Kögel-Knabner I, Ekschmitt K, Flessa H, Guggenberger G, Matzner E, Marschner B (2007) SOM fractionation methods: relevance to functional pool and to stabilization mechanisms-a review. Soil Biol Biochem 39:2183-2207

Werth M, Kuzyakov Y (2008) Root-derived carbon in soil respiration and microbial biomass determined by ${ }^{14} \mathrm{C}$ and ${ }^{13} \mathrm{C}$. Soil Biol Biochem 40:625-637

Yavitt JB (2000) Nutrient dynamics of soil derived from different parent material on Barro Colorado Island, Panama. Biotropica 32:198-207 